\title{
Romanian Marine Centennial
}

\author{
Alexandru S. Bologa ${ }^{\dagger}$ and Roger H. Charlier \\ "National Institute for Marine Research and \\ Development "Grigore Antipa," Romania \\ Academy of Romanian Scientists \\ Free University of Brussels \\ Belgium; Florida Atlantic University \\ U.S.A.
} National Delegate of Romania to CIESM

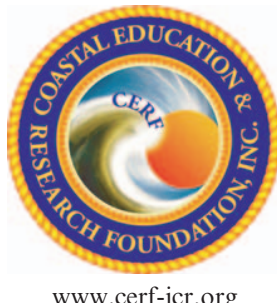

www.cerf-jcr.org

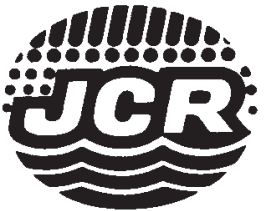

\begin{abstract}
BOLOGA, A.S. and CHARLIER, R.H., 2011. Romanian marine centennial. Journal of Coastal Research, 27(2), 364-367. West Palm Beach (Florida), ISSN 0749-0208.

This article explores an Antarctic expedition that led to the development of marine sciences in Romania, celebrating their one hundredth anniversary, and the creation of marine stations. Emil Racovitza participated in the Belgica Antarctic Expedition of de Gerlache which seems to have nurtured his interest in the marine sciences. He is credited with launching oceanography in Romania. Other major figures in the development of oceanography and the creation of marine research facilities are Borcea and Antipa, whose careers are retraced in the paper. Recently all research points have been regrouped to form the National Institute for Research and Development.
\end{abstract}

ADDITIONAL INDEX WORDS: Black Sea, Emil Racovitza, Grigore Antipa, Ioan Borcea, Romania, Agigea, Constantza.

The fortunate participation of a Romanian scientist, Emil Racovitza, in an attempt by a Belgian navy man, Adrien de Gerlache de Gomery, to reach the South Pole ignited the birth and development of oceanography on the Black Sea Romanian shores. The two were brought together by Pierre-Joseph Van Beneden (1809-1894), who built, using his personal funds, the first marine research and development station in the world in Ostend (Belgium) in 1843. Van Beneden housed what was to be the first laboratory dedicated to marine biology in the oyster nursery of his brother-in-law August Valcke. The Laboratoire des Dunes predates by 16 years the oldest French research station of Concarneau (1859), and those of Arcachon (1867) and Wimereux (1873). The facilities of Sevastopol, Naples, ${ }^{1}$ and Den Helder, also among the first in Europe, date back to 1871, 1872 , and 1876 , respectively.

The Van Beneden family has been associated with academia-in Louvain and Liège - and biology for at least a century. Belgium has been a "first" in many marine sciences avenues. In the field of oceanology and meteorology it organized the first international congress in 1853. ${ }^{2}$ As a result of Van Beneden's solid reputation, foreign and Belgian scientists came in large number to his station. Nothing remains of the station because it was sloped to enlarge Ostend harbour's access channel (Fig. 1a). Its only record is in a print of an old photograph post card.

Van Beneden knew Adrien de Gerlache de Gomery, the Navy officer who planned to set up an expedition to reach the South Pole, and recommended that he consider the Romanian

DOI: 10.2112 /JCOASTRES-D-10A-00013.1 received 1 October 2010; accepted 1 October 2010

(C) Coastal Education \& Research Foundation 2011

${ }^{1}$ Groeben, C., 2008. Tourism in science: 19th century. Proceedings of the California Academy of Science, 59(9), S139-S154.

${ }^{2}$ Charlier, R.H., 2003. Fratres in maribus. The first International Ocean Science Conference. Ocean Yearbook, 19, 1-14. biologist Emil Racovitza (1868-1947) (Fig. 1b) as a team member in the Belgian Antarctic cruise on board the former Norwegian whaler Patria, which was rechristened Belgica in 1897-1898. ${ }^{3}$ Racovitza's contributions to biological oceanography are recalled by a grandson of the expedition's director (de Gerlache de Gomery, 1998) and by Alexandru Bologa (Bologa and Marinescu, 2002) of Mamaia-Constantza's Romanian Institute of Marine Research "Grigore Antipa" at the Fifth International Congress on the History of Oceanography at La Jolla, California (Benson and Rehbock, 1993). ${ }^{4}$

This expedition spurred on Racovitza to turn his attention to the marine realm and to launch the development of oceanography in Romania. Among the founders of Romanian oceanography are two outstanding Romanian scientists, Ioan Borcea and Grigore Antipa, who dedicated their work to the development of marine sciences in the Black Sea and the Mediterranean.

Ioan Borcea (1879-1936), a zoologist (Fig. 1c), created the first Romanian Marine Zoological Station at Agigea (Constantza) in 1926 (Fig. 1d). He specialized in the anatomy and embryology of fish, crustaceans, applied entomology, marine biology, and general biology. Borcea is recognized for numerous achievements, for instance, the introduction of biology in Romanian high school education (including zoology courses), practical training in marine biology, promotion of the theory of evolution, organization of scientific research in Romania, and

\footnotetext{
${ }^{3}$ Charlier, R.H., 2010. Philatelic panorama of some Belgian Antarctic contributions, 19th-21st centuries: From Belgica to Princess Elisabeth. Journal of Coastal Research, 26, 2, 359-378; Bologa, A.S., 2010. Emil Racovitza and the Belgian Antarctic Expedition. Journal of Coastal Research, 26, 2, 374.

${ }^{4}$ Bologa, A.S. and Marinescu, A., 2002. Romanian contributions of Emil Racovitza and Grigore Antipa to the Scientific Exploration of the Mediterranean. Proceedings of the International Congress of Historical Oceanography,5, 275-279.
} 

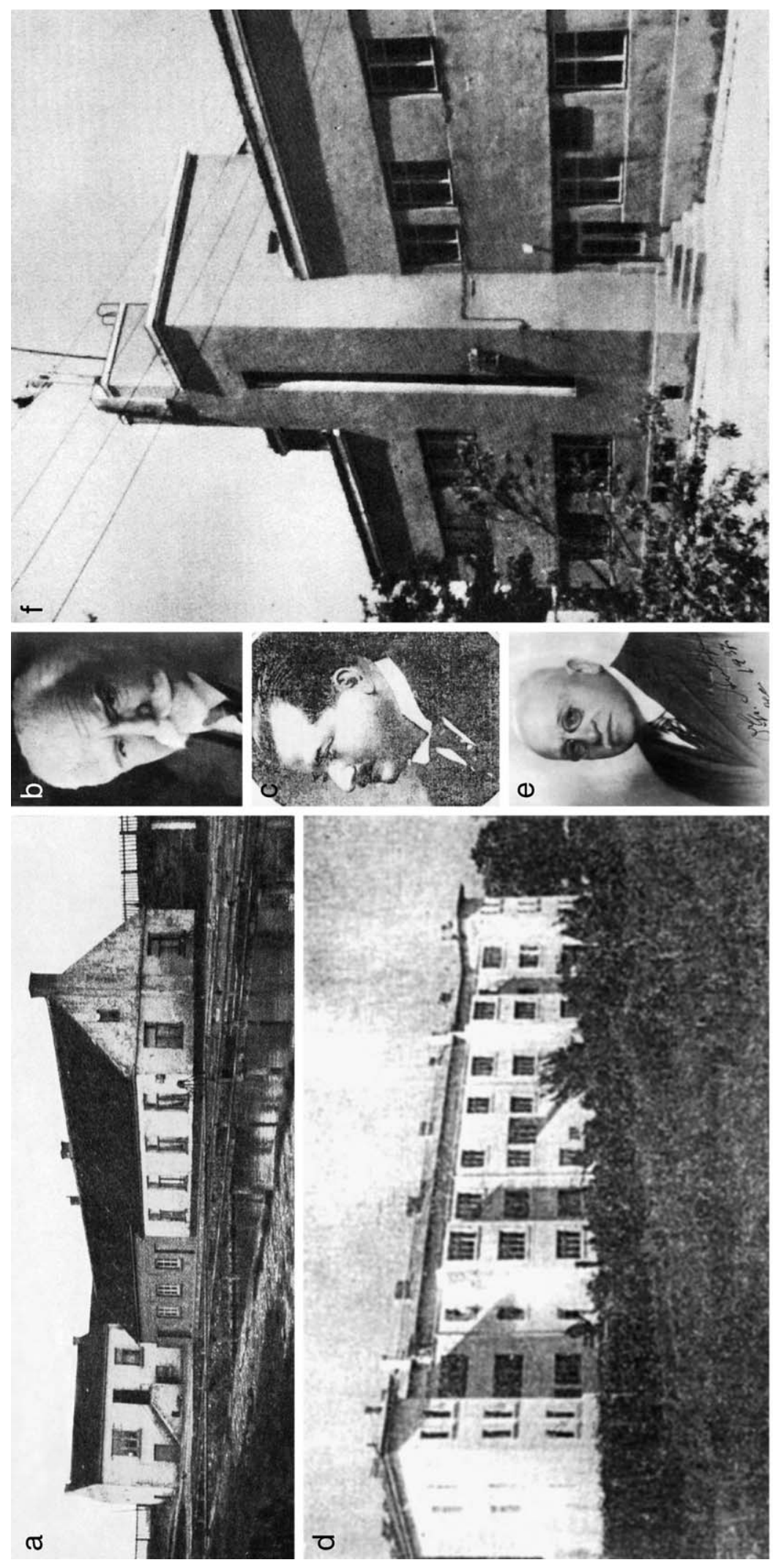

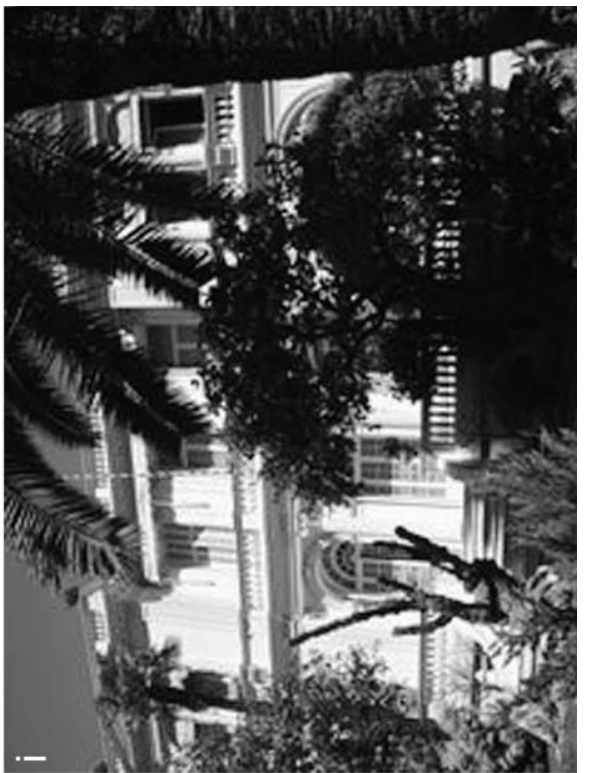

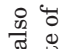

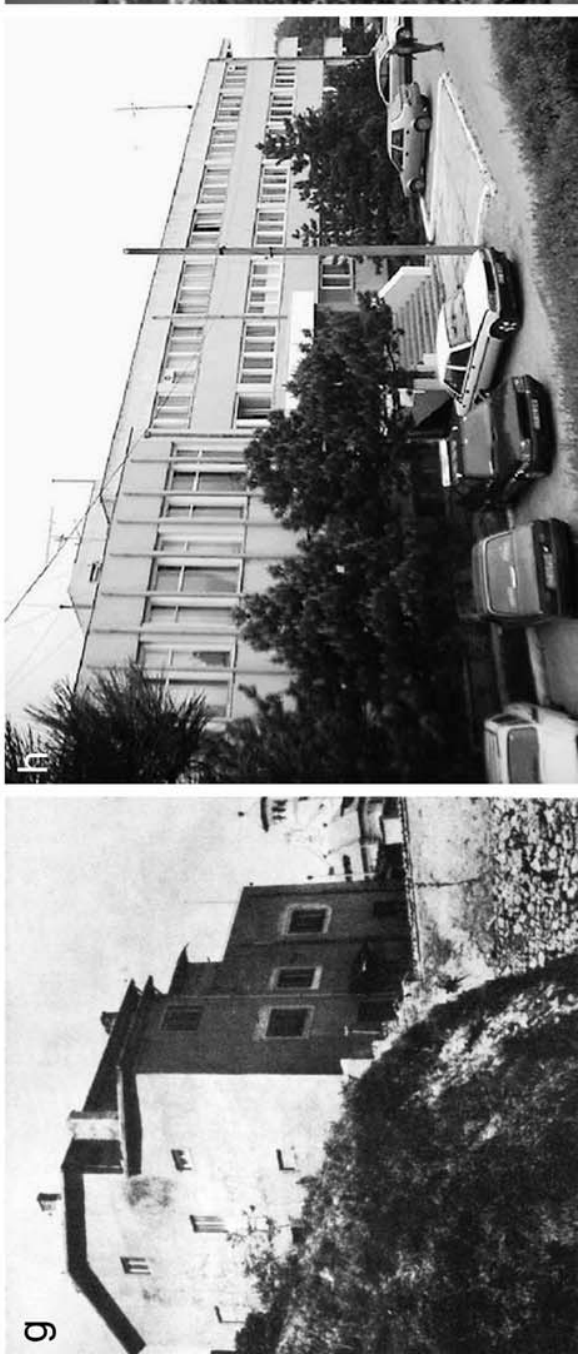

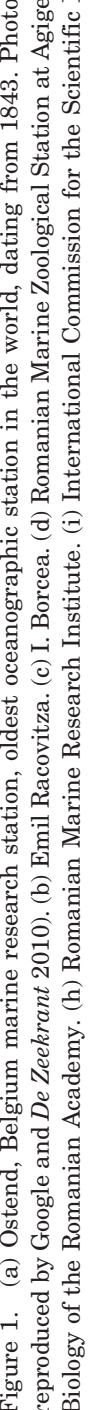


methodological contributions in the biological fight against noxious insects. And Borcea is also known as a humanist, an animateur of the young generations, and a promoter of social progress. $^{5}$

Among the public positions he held are the of deanship of the Faculty of Natural Sciences at the University of Iassy; the directorship of the Museum of Natural History, also at Iassy; Romania's minister of Cults and Public Instruction; a founding member of the Academy of Sciences of Romania (renamed Academy of Romanian Scientists in 2007); corresponding member of the Romanian Academy; member and honorary chairman of the Zoological Society of France; and a knight of the French "Légion d'Honneur."

Grigore Antipa (1867-1944), a marine ichthyologist (Fig. 1e), initiated the first major Romanian research cruises on the Black Sea, aboard the RRN cruiser Elisabeta in 1894, 1895, and 1896. He founded the first Romanian Bio-oceanographic Institute at Constantza in 1932 (Fig. 1f). This expertise led him to major public positions as organizer, director general, and chief inspector of the State Fisheries of Romania. As a result of the international reputation he attained, he was invited by Prince Albert I of Monaco to join the creation of the Commission Internationale pour l'Exploration Scientifique de la Mer Méditerranée (CIESM) in 1910. Because of his prodigious activity, he was officially designated rapporteur for the Black Sea (1927) as CIESM expanded its oceanographic research concerns by adding the Black Sea basin. A year later he became rapporteur for the entire Eastern Mediterranean, including the Black, Marmara, and Aegean seas. Following Romania's governmental adherence to CIESM in 1925, two general assemblies and congresses of this prestigious and most long lived international organization took place in Romania in Bucharest (1935) and Bucharest-Constantza (1966), the former he organized himself.

Most marine research, both in the field and the laboratory, after World War II was led by Mihail C. Băcescu (1908-1999), a biologist, director of the Museum of Natural History "Grigore Antipa" (1964-1988) in Bucharest. Between 1954 and 1970 Băcescu led the Sector of Marine biology of the Institute of Biology of the Romanian Academy in Constantza (Fig. 1g). He was also vice-president of CIESM in 1963 and National Delegate of Romania to CIESM between 1966 and 1999. One of numerous examples of Băcescu's related achievements was the organization, together with fellow biologist Eugen A. Pora (1909-1981), from the University of Cluj-Napoca, and in cooperation with the Mediterranean Association of Marine Biology and Oceanography (MAMBO), of the first international course on the biology of Black Sea brackish waters. The Romanian lectures were published in "Biologie des eaux saumâtres," in a 2 volume set (1977).

At the initiative of M.C. Băcescu and E.A. Pora, the five preexisting marine research related institutions along the Romanian littoral, namely, the Marine Zoological Station "Prof. I. Borcea," the Fisheries Research Station "Dr. G. Antipa" (successor of the Bio-oceanographic Institute), the

\footnotetext{
${ }^{5}$ Bologa, A.S.; Bologa, A.F., and Charlier, R.H., 2004. Ioan Borcea and the first Romanian Marine Zoological Station at Agigea (1926). Noesis, 29, 163-174.
}

Sector of Marine Biology, the Laboratory of Marine Sedimentology (created in Constantza/Agigea by Nicolae Panin in 1964), and the Oceanographic Research Station (created in Constantza by Constantin Bondar in 1967), merged into the Romanian Marine Research Institute (RMRI), located in Constantza, in 1970 (Fig. 1h). The creation of RMRI constituted important progress in the development of Romanian marine research. This institute has carried out complex research cruises in the Mediterranean (Libya), the Atlantic Ocean (Argentina), and the Indian Ocean (Somalia) among others.

The government reorganized RMRI into the National Institute for Marine Research and Development "Grigore Antipa" (NIMRD) in 1999. RMRI/NIMRD's achievements comprise various aspects of research and development, related research and development activities, training activities, national and international programmes and projects, as leading or associate partner, organizer/co-organizer of various scientific events, and participant in congresses, conferences, workshops, exhibitions, trade fairs in Romania and abroad.

NIMRD carries out basic, applied, and technological research, crucial for the knowledge, protection, and management of the coastal zone and marine environment, in the Black Sea Romanian Economic Exclusive Zone.

Besides owning the R/V Steaua de mare 1 (132 mT/570 HP) and directing other facilities, NIMRD has a laboratory for physical and chemical measurements and analyses (LMA) as a specialized structure for marine nutrient loads, pollution monitoring, and trophic values of marine bioresources, accredited by RENAR, according to SR EN ISO/CEI 17025:2005.

Numerous ranking national and international research programmes and projects have been tackled since 1990 by NIMRD and the National Institute for Research and Development of Marine Geology and Geo-ecology (GeoEcoMar) in various contexts: National Programmes ORIZONT 2000, CEMAR, PNCDI I (MENER, AGRAL, BIOTECH, INVENT, RELANSIN, INFRAS), CEEX 2005, PNCDI II, Environment, CNCSIS grants, European Commission/FP5, FP6, FP7, EC LIFE NATURA, MATRA (Senter/NL), GEF Black Sea Programme (1 and 2), bilateral (RO-BG), regional/Organization of Black Sea Economic Cooperation, and with other international organizations such as United Nations Educational, Scientific, and Cultural Organization/International Oceanographic Commission (UNESCO/IOC), the International Commission for the Scientific Exploration of the Mediterranean Sea (CIESM, Monaco, Fig. 1i), the International Atomic Energy Agency, the United Nations Food and Agriculture Organization, the North Atlantic Treaty Organization, and the Agreement on the Conservation of Cetaceans in the Black Sea, as well as in cooperation with indigenous and foreign academies, universities, nongovernmental organizations and scientific associations/commissions/foundations.

NIMRD is the technical operator of the national network for physical, chemical, and biological monitoring and coastal erosion survey, and contributes with its Report on the state of the marine and coastal environment (http://www.rmri.ro) to the Annual National Report of the State of Environment in Romania.

So, NIMRD hosts the National Centre for Oceanographic and Environmental Data, is the national responsible party of the 
international programmes GOOS/Black Sea GOOS and MedGLOSS for sea level, and the scientific responsible agent for the National Programme of marine species collecting and management of fishery data.

NIMRD is also qualified to make regulatory framework proposals for the national environment authority, and to act as Romania's representative in the field of marine sciences, on different international organizations and advisory groups of conventions and agreements with Romanian affiliation.

The following are among the main national and international responsibilities of NIMRD:

- Presidency of and registered office of the Romanian National Committee of Oceanology/CNR-UNESCO.

- Permanent Technical Secretariat of National Coastal Zone Committee.

- Activities coordination and registered office of International Secretariat for SE Europe of Balkan Environment Association (BENA), and of training centre for environmental professions (BENA).

- Activities coordination and registered office for GEF/Black Sea Programme related Regional Activity Centre for
Environmental Aspects of Fisheries and Other Marine Living Resources Management.

- National focal point.

NIMRD plans to celebrate its 40th anniversary at its premises, with a national symposium with international participation, on October 29, 2010. Among invited guests are Luciano Fonseca (UNESCO/IOC); Dmitri Travin (IOC); Hans Dahlin, director EUROGOOS; Violeta Velikova, Black Sea Commission (Istanbul/Turkey); Roger H. Charlier, Free University of Brussels (Belgium); Bayram Öztürk, University of Istanbul and TUDAV (Turkey); Michel Morvan (Brest/France); Bouchta El Moumni, University Abdelmalek Essaadi Larache (Kingdom of Morocco); and representatives of marine research institutions around the Black Sea (Bulgaria, Georgia, Russia, Ukraine). The event is also devoted to the International Black Sea Day (October 31).

\section{ACKNOWLEDGMENT}

The authors express their appreciation to ambassador (ret.) of the Netherlands, Hendrik van Pesch, for his help with some of the pictorial material.

\section{$\square$ RESUME $\square$}

La Roumanie fête le centenaire de son océanographie et l'INRDM (Institut National pour la Recherche et le Dévelopment Marins "Grigore Antipa") célèbre les 40 années de sa création; de fait il s'agit d'un organisme issu de la coalescence de plusieurs stations océanographiques qui ont jalonné le développement de l'océanographie en Roumanie. Plusieurs noms de personalités proéminentes sont citées dans ce bref aperçu. Racovitza, qui se fit un renom en tant que membre du complément scientifique de l'expédition de la Belgica en Antarctique, y trouva probablement sa vocation marine. Les festivités de l'anniversaire, qui ont un cachet international, se centreront sur un symposium.

$\square$ REZUMAT $\square$

Istoricul oceanologiei româneşti poate fi rezumat prin evocarea personalităţilor lui E. Racoviţa, G. Antipa, I. Borcea şi a instituţionalizării cercetării marine în staţiunile şi laboratoarele care au general Institutul Român de Cercetări Marine/Institutul Național de Cercetare-Dezvoltare Marină "Grigore Antipa” şi Institutul Naţional de Cercetare-Dezvoltare pentru Geologie şi Geoecologie Marină "GeoEcoMar."

\section{$\square$ ZUSAMMENFASSUNG}

Die Geschichte der rumänischen Meereswissenschaften kann zusammen-gefasst werden durch die Berufung der Persönlichkeiten von Emil Racovitza, Grigore Antipa und Ioan Borcea sowie die Institutionalisierung der Meeresforschung in Forschungseinrichtungen, die zur Gründung des Rumänischen Meeresforschungsinstitut/Nationalinstitut für Meeresforschung und Entwicklung "Grigore Antipa” und des Nationalinsitut für Forschung und Entwicklung der Meeresgeologie und Ökologie (GeoEcoMar) geführt haben. 
Reproduced with permission of the copyright owner. Further reproduction prohibited without permission. 